\title{
Financial, business and trust cycles: the issues of synchronization $^{* 1}$
}

\author{
Yuriy Bilan ${ }^{2}$, Maryna Brychko ${ }^{3}$, Anna Buriak ${ }^{4}$, Tetyana Vasilyeva ${ }^{5}$
}

\begin{abstract}
Starting from 1920, the growing body of research has been focused on the role of psychological factors in cycle theories. Mainstream macroeconomic models are insufficient for exploring interaction among economic agents, financial institutions, and the real sector of economy. This paper is among the first to show the synchronization of financial and business cycles through the trust cycle but with a certain delay in terms. The paper presents the conceptualization of trust as a combination of two pillars - structure-based confidence based on objective information about system competences, regulations, and norms, and sentimentdriven actions of economic agents (feelings, emotions, and other subjective characteristics). The paper offers a theoretical descriptive model of a trust cycle that allows exploring several stages of correlation between financial fluctuations, trust changes, and large swings in business cycle.
\end{abstract}

Key words: trust cycle, business cycle, financial cycle, economic agents' behavior

JEL classification: E320, E710, G41, O160

* Received: 02-10-2018; accepted: 11-04-2019

1 This work would not have been possible without the financial support of the Ministry of Education and Science of Ukraine. The paper was prepared as part of the Young Scientist Research on the topic "Economic-mathematical modeling of the mechanism for restoring public trust in the financial sector: a guarantee for economic security of Ukraine" (registration number 0117U003924).

2 Associate Professor, Faculty of Management, Rzeszow University of Technology, al. Powstańców Warszawy 12, 35-959, Rzeszów, Poland. Scientific affiliation: labour market, entrepreneurship, energy and society.Phone: +48 506354648.E-mail:yuriy_bilan@yahoo.co.uk.

3 Senior Lecturer, Department of Finance, Banking, and Insurance, Sumy State University, Rymskogo-Korsakova st., 2, 40007 Sumy, Ukraine. Scientific affiliation: application behavior and social science theories and models in macroeconomic fluctuations and growth. Phone: +380542665-075. E-mail: m.brychko@uabs.sumdu.edu.ua (corresponding author).

4 Associate Professor, Department of Finance, Banking, and Insurance, Sumy State University, Rymskogo-Korsakova st., 2, 40007 Sumy, Ukraine. Scientific affiliation: behavior economics, monetary police, banking.Phone:+380542665-075.E-mail: a.buriak@uabs.sumdu.edu.ua.

5 Full Professor, Educational and Research institute of Finance, Economy and Management named Oleg Balatskiy, Sumy State University, Rymskogo-Korsakova st., 2, 40007 Sumy, Ukraine. Scientific affiliation: banking, investments, risk-management. Phone: +38 0542 687-949. E-mail: tavasilyeva@fem.sumdu.edu.ua. 


\section{Introduction}

The global financial crisis has led to the revision of the role of financial sector in economic development, shifting focus of monetary policy from ensuring not only economic growth but also financial stability. After the latest crisis, financial cycle and its variables like asset prices and house prices, have been recognized to be among the main aspects of policymakers' macroprudential approaches due to procyclical nature of financial and business dynamics. Along with the crucial role of financial cycles in economic growth, emerging market economies as well as advanced ones are experiencing high uncertainty risks and low confidence on the side of economic agents. This has led to the situation when expectations of economic agents (optimistic or pessimistic ones) became an important part of the monetary policy transmission mechanism. Expectations are closely linked to decision-making process of both businesses and households, thus determining the financial market volatility and economic activity. Recent research on animal spirits, fundamental factors and business cycle fluctuations (Dées and Zimic, 2016) empirically proved that expecting errors of economic agents can explain almost half of business cycle fluctuations in the short term, while technology shocks explain only up to 20 percent of output variations. Substantial impact of non-fundamental factors - of psychological (behavioral) origin in particular - on business dynamics is evidenced by recent economic research.

Moreover, survey data such as the Edelman Trust Barometer has pointed to a significant de-crease in the trust level in relation to financial institutions. The global financial crisis has been associated with trust crisis featuring credit freeze at many financial markets, the loss of financial institutions' reputation, lack of transparency in financial reporting, collapse of public confidence and trust (Schatz and Watson, 2011; Roth, 2009; Gros and Roth, 2010; Sapienza and Zingales, 2012). Trust becomes crucial for economic dynamics and financial market activity when legal enforceable contracts are absent and confidence in market structures is undermined. Even though significant progress has been made in addressing the issue of financial sector impact on business cycle as well as psychological (behavioral) factors role in financial and business fluctuations, there is no conceptual framework in trust research to show the role of trust in financial and business cycles' fluctuations.

The purpose of the article is to present new theoretical framework explaining causal mechanism between financial and business cycles through trust component. The value added of this paper as compared to the already available literature is twofold. Firstly, we introduce our conceptualization of trust as a combination of two pillars: (1) structure-based confidence that is based on objective information about system competences, regulations, formal contracts and norms, and (2) sentimentbased actions of economic agents including those that could be taken as animal spirits (individual feelings, emotions, other subjective characteristics). The latter dimension is of utmost importance during the periods of major economic shocks 
associated with high uncertainty and risks, and when the credibility of the system is eroded or questioned. Secondly, and more importantly, we develop a theoretical descriptive model of trust cycle that allows us explore several stages of correlation be-tween financial fluctuations, trust changes, and large swings in business cycle. To the best of our knowledge, this is the first work that has the ambition to show the synchronization, but with a certain delay in terms, of financial and business cycles through the trust cycle.

The rest of the paper is organized as follows. Section 2 reviews the related literature on the financial and business cycles' synchronization (2.1), the link between economic agents' behavior and financial cycle (2.2), the relationship between economic agents' behavior (rational (2.3.1), semi-rational (2.3.2), and irrational (2.3.3)) and business cycle fluctuations. Section 3 describes methodology of analysis and presents our conceptualization of trust as well as theoretical descriptive model of the trust cycle. In Section 4 a comprehensive overview of the closely linked financial fluctuations, trust changes and business cycle obtained by estimating the empirical model framework is provided. Section 5 briefly describe results and their economic significance. The last section concludes and provides directions for future research.

\section{Literature review}

\subsection{Financial and business cycles' synchronizations}

Traditionally, the interaction between the real and financial sectors is reflected through financial accelerator models (Bernanke and Gertler, 1989; Kiyotaki and Moore, 1997; Bernanke et al., 1999). Financial conditions of firms and households influence on consumption and investment activity determining GDP growth and in opposite direction.

In time of crisis, the effects of the financial system and the real economy relationships are more crucial since financial sector has increased its size in the world. For example, authors (Reinhart and Rogoff, 2009) have found that vulnerabilities within the financial system (downturns and upturns) may lead to considerable fluctuations in the real sector (recessions and recoveries) triggering macroeconomic destabilization. Credit volumes and house prices booms are found to be one of the most widespread causes of financial crisis (Jorda et al., 2014). Financial and business cycles tend to co-move and be in the same phase significantly more often than not according to the a comprehensive database covering 17 advanced economies over the last 150 years (Jorda et al., 2016). Based on the data of several advanced countries since the 1960s up to 2011 (Drehmann et al., 2012), the financial cycle is much longer than the traditional business cycle, but business cycle recessions are much deeper when 
they coincide with the contraction phase of the financial cycle. It has been empirically confirmed (Claessens et al., 2012) that financial cycles tend to be longer, deeper, and sharper than business cycles. Using multivariate time-series approach to analyze credit, house prices and GDP relationships, the author (Rünstler, 2016) suggests that in most countries financial cycles are, on average, longer and larger than GDP cycles. Financial cycles are much longer and have larger amplitude than business cycles and their peaks coincide with banking crises (Borio, 2014).

Studying financial cycle and its relation to GDP dynamics is usually considered through credit cycle (Borio et al., 2001) or a set of financial variables - asset prices, volatility index, default rates, non-performing loans (Adrian and Shin, 2009). Household debt expansion in the form of credit-driven household demand channel is also found to have a close relationship with the business cycle predicting dynamics of GDP (Mian et al., 2017). Schularic and Taylor (2009) pinpoint some evidence that the financial system provokes economic instability through endogenous credit booms. However, the degree and source of causality between financial cycle variables and future activity are not always clear. Empirically the extent of synchronization between business and financial cycles is usually confirmed through analyzing the concordance between macroeconomic variables (Harding and Pagan (2002), Cashin et al. (1999)).

Valuable strand of the literature on exploring interaction between business and financial cycles fluctuations point that duration and amplitude of business cycles are influenced by the strength and intensity of financial cycles (Kose et al, 2009, Claessens et al., 2012). Moreover, empirical results indicate that recessions accompanied with financial disruption tend to be longer and deeper amplitude than the traditional business cycle (Borio, 2014). In the context of cross-country analysis, it is found that recessions and financial disruptions in emerging markets, compared to the advanced countries, are more expensive and protracted. Capturing reasons that drive financial and business fluctuations are basically based on perceptions of risk and attitudes towards risk. The case of Denmark shows that there are signs of over-optimism and mispricing of risk prevailed during the years leading up to the financial crisis of 2008-09 (Grinderslev et al., 2017; Danielsson et al., 2016). Although these findings do not account for non-fundamental factors - behavioral - that could influence the nature and lags in financial and business cycles. In this article we will address this gap by incorporating a trust cycle drawing on behavioral approach in decision-making of economic agents to explain why financial cycles are much longer than business cycles.

\subsection{Economic agents behavior and financial cycle}

The recent crisis has demonstrated the importance of financial markets volatility responsible for sluggish real economic development and creating financial fragility. 
A certain strand of this literature has been concerned with endogenous nature of financial fluctuations stressing out the crucial role of the firm balance sheet positions and debt financing of investment. This view dates back to Fisher (1933) and Keynes (1936) and supported by Minsky (1983) distinguishing "hedge", "speculative" and "Ponzi" finance. Recent asset price bubbles were caused by over-extended lending (Miess et al., 2016), financial innovations like securitization. In another strand of the literature, research efforts have been made to incorporate exogenous sources of financial fluctuations related to financial market imperfections, information frictions, financial regulations, behavioral biases etc.

Whatever view is taken as basic, there is consensus that economic agents behavior and their decision-making process is central point for provoking financial fluctuations and fragility. From the standpoint of neoclassical framework actions of economic entities are viewed as elements of an efficient capital market allocation. The new literature on financial cycle points the constraints on efficient capital market allocation (financial market imperfections and anomalies) caused by information failings like asymmetric information and failings in the rational behavior of agents (behavioral bias). The recognition of imperfect information, costly process of obtaining information, existence of important information asymmetries affects agents' behavior (Stiglitz (2000). Asymmetric information shown by Akerlof (1970) as 'lemons' problem illustrates adverse selection arises when the informed individuals make decisions depend on their privately held information in a manner that adversely affects uninformed market participants.

Behavioral biases encompass psychology aspects of financial booms and busts. Beliefs, opinions, feelings of economic agents are in the focus of financial decisionmaking - there are examples of "animal spirits" of Keynes' terminology or stage of euphoria related to "Ponzi finance" in a typical credit cycle by Minsky. Decisions of economic agents including investors are hampered by cognitive errors or misleading emotions which can be related to individual errors, collective biases (for example, contagion effect), generic market inefficiencies (Kahneman and Tversky, 1979). Overconfidence and over optimism, conservatism, framing and anchoring, mental accounting, representativeness, loss aversion are among the most widespread biases impacting investor behavior in financial market and provoking bubbles and inevitably financial fluctuations. Overconfidence is regarded as the main trigger of the global financial crisis in the US market and in other continents (Jlassi et al., 2014), in financial market it leads to increased trading activity, higher risk taking, and less diversification (Merkle (2013), Mentel et al. (2017), Belás et al. (2016). Identification of behavioral biases' impact on financial market volatility is relevant for both investors and regulators and reinforces the importance of considering investor sentiment to better understand the behavior of financial markets (Horta and Lobão, 2018). 


\subsection{Economic agents behavior and business cycle}

In the economic theory expectations, there are essential basic elements for aggregate economic behavior as they are tied to attitude, opinion or judgment based on feelings and reflect agent's views on future economic development. Based on personal views, these opinions can generate waves of optimism and pessimism (sentiments) and can be reflected through dynamics of consumption expenditures, employment and GDP. It should be noted that the idea of economic agents expectations impact on business cycle is not new in economic theory dating back to Beveridge (1909), Clark (1917), Pigou (1927) and Keynes (1936). The mentioned academic literature claims that any changes in economic agents' mood generate fluctuations through changing consumer demand and investment activity.

\subsubsection{Rational-agent behavior model}

The current standard methodology for modeling expectations is to assume rational expectations (Evans and Honkapohja, 2001). The global financial crisis of 200708 was renowned as "confidence crisis" characterized by low rate of confidence and distrust stimulating studying confidence indicators. It reveals the "information" view which is based on confidence indicators that contain information - signals about future economic developments and positively/negatively affect future economic decisions and behavior (Beaudry and Portier (2014), Gazda (2008).

The rational choice theory, also referred to as a rational action theory, relies on the assumptions that economic agents are based on gathered information on markets; on probabilities depending on some desirable/undesirable events that may occur; on using intelligent guessing while calculating potential benefits and costs in determining complete, consistent preferences, and in that way make the selfdetermined best decision that optimizes their utilities or goods. According to this approach, market volatility could be explained by the rational bubbles (Blanchard (1979), Blanchard and Watson (1982), Aoki and Nikolov (2015). This may be due to imperfection in the logistics of the market process that impede efficient arbitrage (Dow, 2009). The latter could be reflected in misleading and misinterpretation of economic agents provoking behavioral errors and results in news-driven economic cycle fluctuations. Analytically using confidence indicators based on objective information allow economic agents to make rational decisions. In case of failing confidence-building mechanisms of trust, irrational decisions start to play a prominent role in decision making process.

\subsubsection{Semi-rational-agent behavior model}

A large and growing body of academic literature on decision making has revealed the emergence of several approaches to the distinction between rationality and 
irrationality of economic agents. This means that cyclical fluctuations are rooted by fundamentals macroeconomic changes based on psychological waves (Acharya et al., 2017). In the economic literature, the latter approach has come to be known as the bounded rational approach, also referred to as semi-rational economic agents or agents with cognitive limitations. Awareness of semi-rational decision making is not recent, having been first described possibly as the theory of bounded rationality in 1957 by Herbert Simon (Simon, 1957). ???

Following, Kahneman (2003), Bidder (2015) and De Grauwe and Ji (2017) due to the economic agents' uncertainty about complexity of real world they are guided by simple rules of behavior. Rational qualities and completely reasonable decision could be made only by professionals in the economic sphere, including finance, while others owing to the lack of financial background are driven by sentiments. However, they are able of the "adapting learning" (De Grauwe and Ji, 2017) based on their forecasts performance (mistakes or correct decisions) in the past. The upshot is that changes in behavior of bounded rational economic agents, based on the information they have and rules that they use, could be considered as the herald the beginning of a new stage of the business cycle.

Compared with the concept of agents with cognitive limitations, economic agents are incapable to make an optimized decision due to the limitation of the availability of information and given the time constraints available for the decision making. The above mentioned cast doubt on theory of the efficient market. Di Bella and Grigoli (2018) found that private economic agents based on information learning about future potential output growth adjust their current demand accordingly over the two years following the shock in expectations. The evidence reviewed here seems to suggest that optimism/pessimism swings of economic agents could be viewed as reaction to changes in fundamental trigger rational actions of agents.

\subsubsection{Irrational-agent behavior model}

Some modern explanations of cyclical fluctuations have to be looked for outside rational framework and based on sentiment-based actions of economic agents concept of animal spirits ("sunspots") - reflecting changes in beliefs based not on the fundamental factors (such as prices or income) but on the individual attitudes (Akerlof and Shiller (2009), De Grauwe and Ji (2017)). One of the favorable environments for action of psychological drivers is high uncertainty shocks.

In previous studies on expectation shocks, psychological biases such as optimism and overconfidence have been found to be related to the business cycle volatility (Brunnermeier and Parker (2005), Jaimovich and Rebelo (2007). This statement may appear to be contradictory from the point of view of standard neoclassical growth model; it is, however, coherent with the explanation of exhibiting periodic cycles and chaotic behavior of economic agents as a driving force for the business 
cycle volatility. By drawing on the concept of behavioral economics, Jaimovich and Rebelo (2007) has been able to show that both overconfidence and expectation shocks could be a potentially useful amplification propagation mechanism, but could not be viewed as sole drivers of business cycle.

Other researchers, however, who have looked at irrational urges, have found that pessimism leads to significant business cycle fluctuations (Bidder (2015), Prince (2017). Following Hansen and Sargent (2008), they claim that economic agents at their core are pessimists, given that they make economic decisions based on the fear that their benchmark is wrong, and therefore, they implement the worst-case model in life. Thus, in times of high volatility and uncertainty, there is no space for economic agents' confidence, therefore, the economic agents are guided by animal spirits. The irrational behavior of economic agents expressed in the high level of pessimism in the economy leads to the general contraction in business activity.

In contrast to the aforementioned findings, according to Gomes and Sprott (2017) the economy reaches equilibrium only when economic agents are equally distributed among optimists, pessimists and neutral. This notion is supported by the fact that in case of domination of optimistic expectation, the economy may overinvest; conversely, if pessimism prevails, the economy may under-invest. Both can lead to the boom and bust of the business cycle. Therefore, an economic outcome is more favorable when the number of optimists and pessimists are balanced, and they are neutral on average.

\section{Methodology of the analysis}

In the vast area of empirical scientific research and study of the role of trust in business and financial cycle fluctuation, the original institutional economics approach to the notion of trust developed from the work of Luhmann $(1979,1988)$ is used. And therefore, the growing body of scientific literature proceeding from intention/competence duality applied the concept of competence-based confidence in order to explain the current financial crisis. This concept is built on a requirement for the trusting agent intentions, because otherwise our expectations are formed in confidence. Due to the complex nature of banking system, its decision making can have both intentional and unintentional elements. The following example is taken to illustrate the above mentioned: despite the fact that there is a new more profitable option to put money in securities due to their good potential to rise, an economic agent trusts that a bank will honor its commitment to give out an agreed loan,. However, trust does not apply to an economic agent's expectation of the bank ability to provide money in time, in agreed amount and under agreed interest on using the credit line. This expectation applied to a bank or other financial intermediary competences is confidence. 
Nooteboom (1996) and later Beugelsdijk (2006) following Luhmann (1979) indicated the need for existence of economic agent's choice to enter the relationships with the trustee, if there is no choice, the relationships are grounded on competence-based confidence. Taking into account the financial services diversity this approach cannot be merely applicable. When we talk about settlement and cash servicing, the economic agent cannot have trust in the banking system, but instead, he or she has a level of confidence in it competence to transfer the money from one account to another. However, in case of doing investments in the form of deposits in a bank, there is always a choice (alternatives): to buy gold, securities or foreign currency from money speculators bypass the centralized banking system. It is in this regard banking system couldn't be analyzed solely through confidence indicators.

Hughes (2010) by combining intention/competence with the agency/structure approaches developed an agency-based trust and structure-based confidence. Given that only agency has the ability to make a choice and to have intentions, the expectation could be applied to trust. While institutions (institutional structures) are based on formal rules and regulations (no space of intentions), therefore, the expectation could be applied to confidence. Regardless stages of the banking system development, as well as financial cycle phases, trust and confidence are always inherent characteristics.

Our conceptualization of trust is based on the structure-based confidence developed by Hughes (2010) based on Luhmann (1979), Nooteboom (1996) and Beugelsdijk (2006), but not limited to it. When the system is reported to have worked well within the framework of ongoing formal mechanisms and norms, trust would be formed on structure-based confidence. However, a certain level of structurebased confidence is not always enough for establishing the sufficient level of trust to ensure sustainable economic development. Especially in times of financial volatility, a vital role in creating the conditions of trust is played by sentiment-based actions of economic agents. Therefore, confidence could be viewed as a source of trust, sometimes as a complement to trust, but never as a substitute. Growing structure-based confidence could be reflected in an increasing trust. And at the same time, a sudden plunge in trust caused by a reduction of confidence due to the system inefficiency could be compensated by manipulating the sentiment-based actions of economic agents.

The cyclicality of household and business confidence strengthened by the waves of optimism and pessimism in the financial sector reflects fluctuations in the level of economic activity. Thus, the business cycle can be investigated through the prism of trust, but with a delay in terms of their synchronization. By revealing the determinants of trust it can be argued that the volatile trust dynamics, in the conditions of overfinancialization of the economy, is determined by the cyclical nature of the financial sector. However, it has a pro-active character. Thus, the 
dynamics of change in trust, the financial sector and the economy as a whole do not coincide. Akerlof and Schiller (2009) also pointed out that the growth of stock prices leads to an increase in people's trust, their consumption, and, accordingly, the growth of producer's profits, which leads to the subsequent increase in stock prices. In order to reflect the pro-cyclical nature of trust in the financial sector, it is advisable to present a descriptive model of financial sector development combined with a shift in the trust cycle and the business cycle (Figure 1).

Figure 1: Descriptive model of the trust cycle and its synchronization with business and financial cycles: A tentative conceptual framework

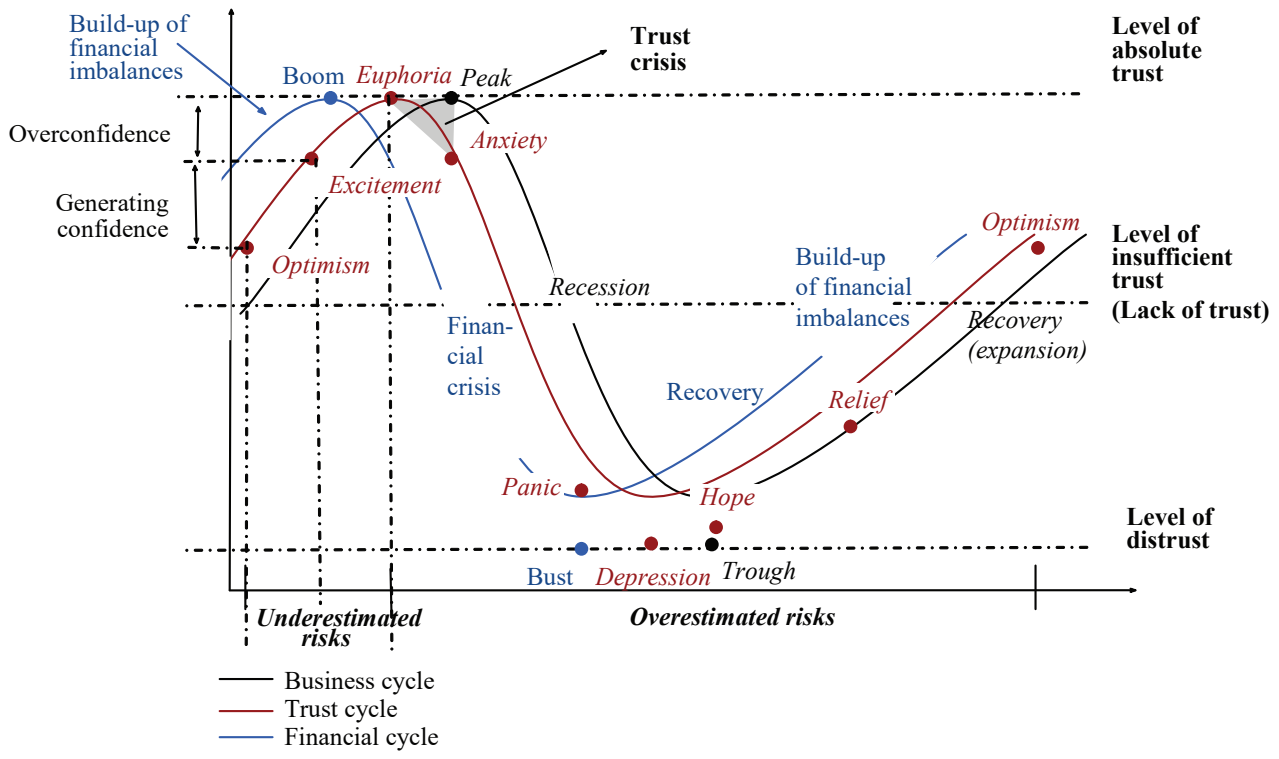

Source: Authors' design

The trust cycle could be interpreted as recurrent trust fluctuations, which may be different in nature of origin, duration, and amplitude of the oscillations, over the years under the influence of objective (structure-based confidence) and subjective (sentiment-based actions of economic agents due to the emotional origin) factors. A length of the trust cycle is determined by the duration of the financial system stability and the economy as a whole. Accordingly, the longer is the periods of instability in the financial system, the greater is the volatility of trust in this system, and the economy as a whole. In other words, the insufficient level of trust comprising lack of structure-based confidence of economic agents is formed. The amplitude of the trust cycle oscillations is not a constant characteristic and depends on the depth and duration of the financial and economic crises and the scale of the shocks of economic agents. This means that the greater losses of households and 
businesses due to the negative impact of financial sector imbalances, the longer the process of trust restoring and, accordingly, achieving its maximum value.

The start of the deployment of the new financial cycle could be caused by various impulses of innovation or financial shocks. In order to ensure future economic growth by many Governments of many countries steps are taken to mitigate monetary conditions and apply the policy of "cheap money" to provide liquidity in the financial sector of the economy. Accordingly, economic agents, under the influence of the positive development of the financial sector of the economy, gradually increase the volume of their transactions. For households, this period is characterized by an increase in consumption, for business, respectively, - by increasing its production capacity or starting the re-equipment of production. Thus, the country's economy is at a stage of recovery characterized by a growth of GDP and revenues of all economic agents, employment and prices.

As a result of the positive dynamics of financial and economic development, economic agents have a sense of confidence based on objective macroeconomic forecasts and optimism - subjective irrational expectations. In order to generate short-term profits in the short run, economic agents are buying up speculative financial assets and real estate for their further resale. In this phase of the financial cycle for the banking sector is characterized by credit expansion (credit "boom"), which reduces investment in the real sector of the economy and expansion of unproductive investment. Positive expectations of economic agents about possible economic benefits begin to be justified, with the level of return on investment above the bank interest rate.

The second stage of economic development, characterized by a significant increase in prices for financial and real assets, which are determined solely by the expectations of their further growth, multiplies the "wealth" effect of economic agents and encourages their further increase in lending. During this phase, the financial system begins cumulative accumulation of imbalances in the financial sector through further expansion of lending and new innovative methods and sources of financing (financial innovations). Compared to the financial cycle, which is at the highest point (peak of the cycle), the trust cycle is still not reaching its maximum value.

However, against the backdrop of general emotional upsurge, the "trust multiplier" enters into action, which, accordingly, increases the level of trust and strengthens the overconfidence of economic agents in the context of underestimation of risks. Investment decisions by economic agents are taken instinctively. Accordingly, such a positive dynamics prompts further growth of the country's economic development. However, significant gaps between the change in the volume of the money supply, real GDP, and available credit resources are taking place. For this reason, at the time of plunging financial markets and real estate asset prices 
(the explosion of the financial "bubbles"), trust is in the highest phase of the cycle. Economic agents that profit for a while are in a state of euphoria, fueling the upward movement of real GDP, despite the aggravation of instability in the financial sector of the economy. Although the country's economy is at the highest point of its growth, further devaluation of the national currency, manifestations of liquidity problems, tightening of monetary conditions, changes the euphoria's sense to growing anxiety and worrying about obtaining negative economic losses. It is precisely in the period when the business cycle is at the highest point (the peak), and in a society the euphoric feelings that have no objective basis change into anxiety, such a social-psychological phenomenon as a trust crisis is taking place.

During the period of the credit crunch, the liquidity crisis, the strengthening of the devaluation of the national currency, societal concerns is changing into a panic. The panic of economic agents is compounded by a loss of trust between the institutions of the financial sector of the economy (between financial and credit institutions, the NBU and commercial banks). The negative consequence of such processes is the phasing out facilities that manufacture different products, reflected in a disturbing increase in bankruptcies among small and medium-size companies, growing unemployment, lowering living standards, scaling-back of social programs. As a result of the implementing stabilization programs and structural adjustment, stabilization the national currency and mitigating monetary conditions are achieved by the Government. However, society could not rapidly recover from financial shocks and upheavals; economic agents are characterized by a sense of disbelief that corresponds to the lowest level of trust - distrust. Distrust that takes place in interpersonal relations, as well as distrust with respect to financial and credit institutions, rating agencies, central banks, regulators and certain sectors of the economy, leads to a decline in real GDP (the business cycle reaches the lowest point - the trough). The particularly dangerous situation takes place when society is in a perpetual steady state of despair, which in severe cases can lead to social depression of economic agents, and, as a consequence, a depression of the business cycle.

Meanwhile, the financial sector begins to accumulate a sufficient level of liquidity. In the recovery phase of the financial cycle, economic agents tend to overestimate risks, although the gradual increase in financial asset prices encourages households and businesses to believe in possible future economic gains. This prompts the next revival of production and commercial activity and serves as the next stage of the economy's recovery from the crisis. Further emotional components of trust (hope and optimism) become the psychological basis of the country's economic growth.

The existing literature on financial cycles and their interaction with business cycles is extensive and focuses particularly on how financial market developments influence the business cycle as well as in what way financial booms provoke a financial crisis followed by economic crisis. An overview of this strand of research, behavioral biases as a consequence of financial constraints, uncertainty, or periods 
of stability, and its role in future economic development is provided in part 2. A general consensus has been reached that financial cycles are in general longer, more pronounced than business cycles with downturns (upturns) deeper and more intense than recessions (recoveries). A tentative conceptual framework depicted in Figure 1 incorporates key assumptions about financial and business cycles and makes an emphasis on the short- and medium-term. A number of techniques have been developed to define the financial cycle; therefore, the choice of a specific method depends on the task at hand. Descriptive model of the trust cycle and its synchronization with business and financial cycles corroborate the ideas of Krznar and Matheson (2017), who suggested that business cycle measured by real GDP growth lags the financial cycle by one quarter in medium-term concept (financial cycle measured by credit cycle) and by two quarters in short-term concept (financial cycle measured by financial conditions index). Figure 1 also support previous research into this brain area, which indicates that financial and business cycles move in tandem. In line with Kaminsky et al. (2003) and Calvo and Mendoza (2000), a tentative conceptual framework explains contagious nature of financial upturns and downturns by economic agents behaviour related to certain level of trust formed by structural-based confidence and sentiment-based actions.

\section{Empirical analysis}

In the study conducted by Hughes (2010), it was shown that the intertwining and separation of trust and confidence are in line with stages of banking system development. It has been demonstrated that confidence crowds out the importance of trust as the banking system develops, however, never replace it. Our intention is to show that while financial cycle phases follow one another, the balance between trust and confidence shifts towards confidence or trust depending on uncertainty and risk.

Stage characterized by absolute trust acquired through high level of structure-based confidence and positive sentiment-based actions of economic agents

Special attention in the economic literature and the media was given to trust, usually during times of exacerbation of the crisis phenomena of the country's economic development, overcoming the consequences of the financial crisis and finding ways out of recession (Roth, 2009). Proceeding from the theory of naturalecological and socio-economic cycles of the global recession, after the financial crisis of 2007-2008, another economic boom was preceded. In 2000-2008, the GDP of the leading countries of Europe and the United States increased by a third, while Ukraine multiplied GDP growth by almost four times (Figure 2a). The ratio of the unemployed to the total number of economically active population during the precrisis period decreased annually (Figure $2 b$ ). 
Figure 2: Indicators of macroeconomic development

Figure 2a: Growth rates of GDP, in $\%$ to the previous year

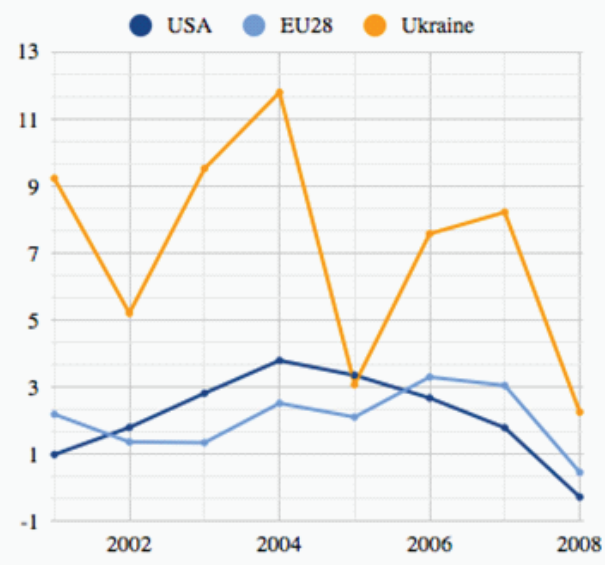

Figure $2 \mathrm{~b}$ : Unemployment rate, $\%$

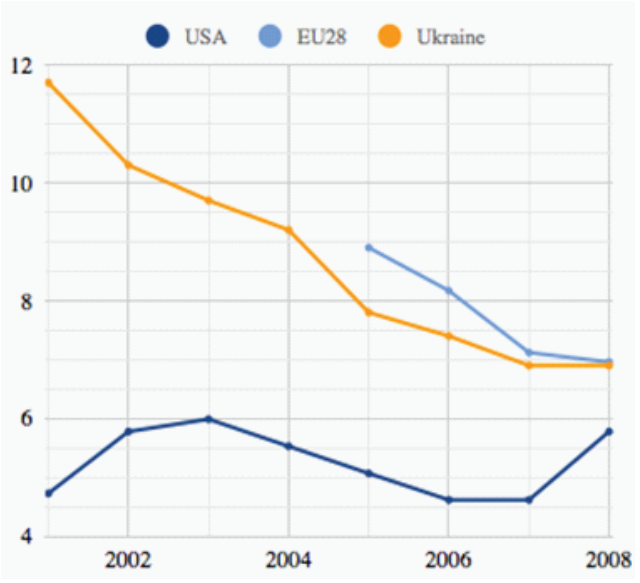

Source: OECD, State Statistics Service of Ukraine

Since 2003, most of the added value has started to be created in the field of providing financial and information-consulting services and were one of the sources that contributed to the cyclical processes that spread throughout the world economy. The economies of the leading countries were not characterized by deep cyclical shocks, and, respectively, household and business sentiments were optimistic; consumer and business confidence grew in industry, construction, retail and services; the level of trust reached its maximum value.

Optimistic expectations about incomes have encouraged households to increase their discretionary costs, which are determined not only by economic determinants but also by instinctive irrational factors. The positive dynamics of revenue and expenditure growth has created a peculiar multiplied effect of increasing confidence. The confidence multiplier was developed by Akerlof and Schiller on the basis of the multiplier Keynes. Thus, the growing confidence of households in the future of the country's economic development in the early 2000s, and their trust as a whole based on rising household incomes and employment, increased the economic activity of the population in terms of spending, including through consumer lending. The increase in the consumption has led to an increase in production and, as a result, business incomes. Accordingly, resulting income growth reinforced that confidence. This led to higher income growth for all interrelated parties and a general level of trust (Figures 3a and 3b). 
Figure 3: Confidence of households and business entities in the pre-crisis period

Figure 3a: Consumer confidence index Figure 3b: Business confidence index (CCI)

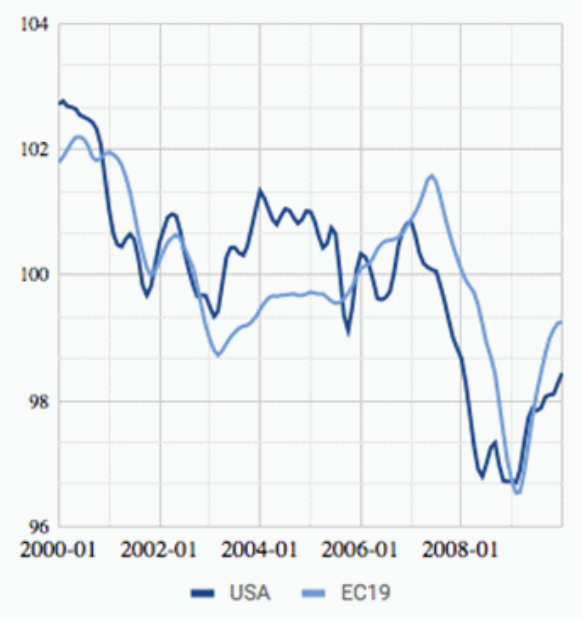

$(\mathrm{BCI})$

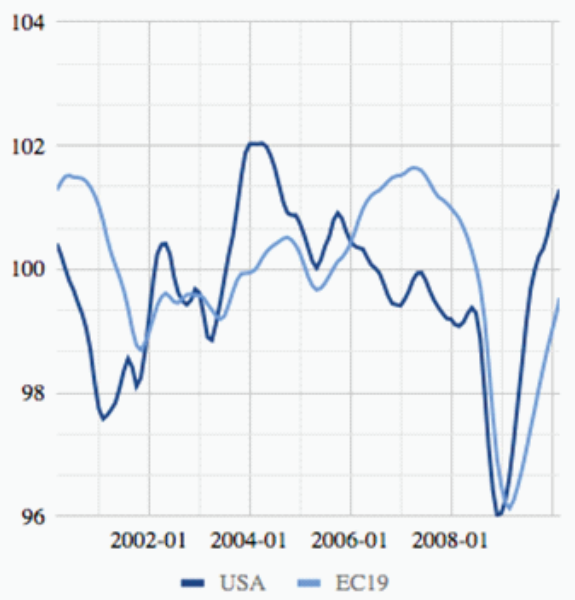

Source: OECD

In this case, it can be argued that the level of trust is a pro-cyclical indicator, which is slightly ahead of the country's economic growth. The absence of economic and political shocks leads to an increase in confidence and such optimistic mood stimulate economic activity, and therefore a general level of trust which is reflected in the growth of macroeconomic development indicators. Thus, there is a certain trust cycle that determines cycle of economic development with a certain time lag.

Since economic forecasts were optimistic, during 2005-2006 financial institutions increased the volume of consumer lending. The US economy was characterized by excessive lending to housing construction in the context of overall growth in consumer lending. Financial bubble was fed on the optimism it generated until it burst. Thus, in middle 2007, conditions for the onset of a cyclical crisis were created. Therefore, as a result of a substantial drop in housing prices and rising interest rates on loans, many investors have suffered heavy losses, which has been the impetus for a crisis that has spread from the housing market to other sectors of the US economy and then to other economies.

Since mie 2007, negative phenomena of economic development have caused pessimistic sentiments in society. Recent studies reveal the existence of many reasons why institutions or the system as a whole ceased to be trustworthy. Tonkiss (2009) identifies three mechanisms of economic confidence - information, contract, 
regulation - that play the cruciale role in making specific institution or wider economic systems trustworthy. Taking into consideration the failure of mechanisms stated above, the prerequisites for the loss of trust derived from eroded structurebased confidence were created and, thus, the 2008 trust crisis was inevitable.

Stage characterized by the absence of trust (distrust) resulted from the loss of structure-based confidence and negative sentiment-based actions of economic agents

The general crisis of trust in 2008 has become an independent factor, which determines the low efficiency of the adopted regulatory developments in the wake of economic recession, since trust was undermined not only in the certain financial instruments or institutions (structure-based confidence) but also to regulators and socioeconomic systems as a whole (Figures $4 \mathrm{a}$ and $4 \mathrm{~b}$ ).

Figure 4: Confidence of households and business entities in the post-crisis period

Figure 4a: Consumer confidence index Figure 4b: Business confidence index

(CCI)

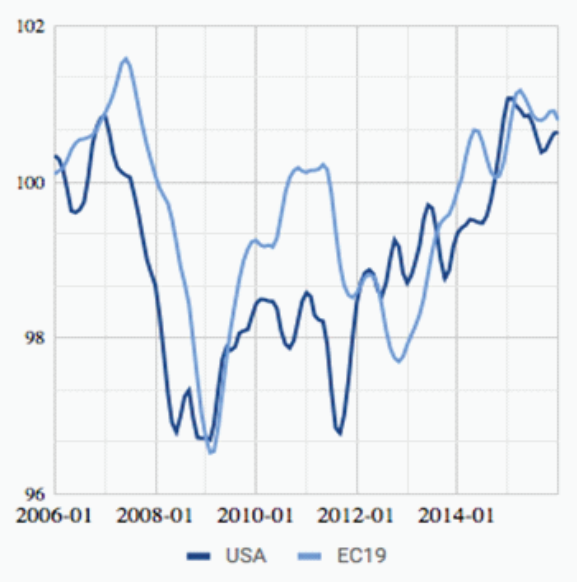

(BCI)

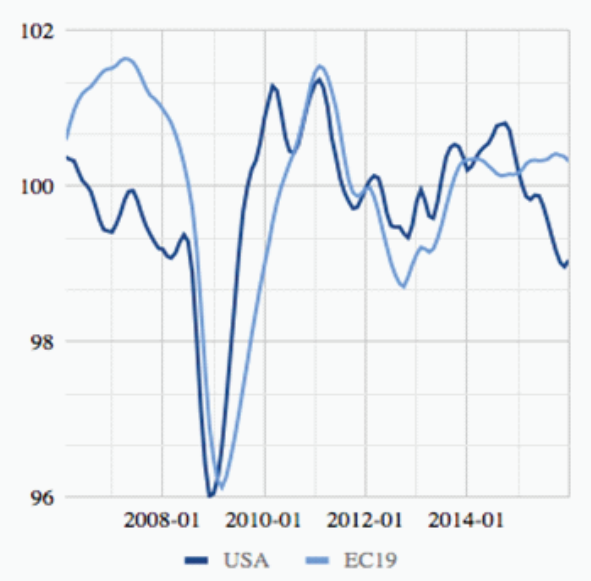

Source: OECD

Lack of trust eroded the effectiveness of such traditional monetary instrument of calming stressed markets and regaining financial stability as lowering interest rates. Panic at the time of the escalation of the financial and economic crisis was also associated with official statements regarding the recognition of a large number of banks as troubled financial institutions, bankruptcy of systemically important or "too big to fail" financial institutions, in particular in the United States of 
America and United Kingdom, which entailed further steps in future mergers and acquisitions transactions.

The effect of the uncertainty of households and business entities was magnified by statistics of negative financial results of banking systems in most countries: in the second and third quarter of 2009, banks began to experience losses or a slight net profit.

Stage characterized by lack of trust derived from volatility sentiment-based actions of economic agents

A key feature of this stage is to maintain the downward trend in structure-based confidence and a high level of trust volatility as a whole. In response to the negative repercussions of the financial and economic crisis as well as the growing effects of the recession, many Governments have taken steps to restore structure-based confidence in the financial sector within the framework of stabilization mechanisms to prevent the financial crisis (the EU is the European Economic Recovery Plan, 2008), the European Financial Stabilization Mechanism, 2010), Single Supervisory Mechanism, 2013), etc.). The low efficiency of the proposed tools is explained by the "ratchet effect" that is used to explain an instance of the restrained ability of price to be reversed once its sharp increase had happened in the past. Thus, the loss of trust in 2011 was not subject to its rapid recovery in 2012 due to the difference in the processes of loss of trust and its restoration. And more importantly, all stabilizing mechanisms were directed towards rebuilding structure-based confidence rather than sentiment-based component of trust. Consequently, at present, the problem of restoring both structure-based confidence and sentiment-based component of trust in the financial sector remains the fundamental objective not only of financial markets regulators but also of many Governments all over the world.

\section{Results and discussion}

The present study was designed to determine the role of trust in explaining the causal mechanism between financial and business cycles. A careful study of the existing literature shows that trust is a highly complex and ambiguous phenomenon. We argue that trust could not be simplified to confidence indicators. Trust is essential and central asset for trade, financing, investments and other activities in economy and determines economic decision-making. Significant slowdown followed by deep recession in 2009 failed to be explained by neoclassical economic models as missing link was falling trust in financial markets and institutions. One of the main reason for volatile trust is financial fluctuations and instability as a result financial crisis became trust crisis followed by loss of confidence and people's willingness for economic activities in future. Crisis of trust extended financial system (institutions, markets) to economic system in general (including 
policymakers) provoking economic crisis. Therefore, this paper first of all draws relevant theoretical insights of trust role as channel and missing link between financial and business fluctuations. The empirical findings in this study provide a new understanding of trust that is established on the basis of structure-based confidence (especially when the system is reported to have worked well within the framework of ongoing formal mechanisms and norms) and sentiment-based actions of economic agents (especially in times of financial volatility). Therefore, confidence could be viewed as a source of trust, sometimes as a complement to trust, but never as a substitute, that is in contrast to earlier findings.

This combination of findings provides some support for a tentative conceptual framework that suggests the existence of the trust cycle. Trust cycle displays recurrent trust fluctuations, which may be different in nature of origin, duration, and amplitude of the oscillations, over the years under the influence of objective (structure-based confidence) and subjective (sentiment-based actions of economic agents due to the emotional origin) factors. The length and amplitude of oscillations of the trust cycle are determined by the depth and duration of financial sector imbalances as well as the scale of the shocks of economic agents. This finding, while preliminary, suggests that the trust cycle is a channel of synchronization of financial and business cycles but with a certain delay in terms. An empirical analysis based on indicators of macroeconomic development (growth rates of GDP, unemployment rate) and confidence indicators of households and business entities (CCI, BCI) in the pre- and post-crisis period proved the macroeconomic consequences of public trust crisis due to financial imbalances. It also helps identify several stages of interactions between financial fluctuations, trust changes and swing in business cycle - stage characterized by high level of structurebased confidence and optimistic sentiment-based actions of economic agents, stage characterized by the absence of trust (distrust) resulted from the loss of structurebased confidence and pessimistic sentiment-based actions of economic agents, stage characterized by lack of trust derived from volatility sentiment-based actions of economic agents. These results provide further support for the hypothesis that a certain level of structure-based confidence far not always enough for establishing the sufficient level of trust to ensure sustainable economic development. That testified to the importance of sentiment-based actions of economic agents in times of financial volatility.

Despite strong theoretical and empirical evidence on financial and business linkages, the source and origin of lags between financial and business cycles remain undertheorized and sufficient explored. Drawing on a behavioral approach in decisionmaking of economic agents, we present trust cycle as embedded inherent element in the financial as well as business cycle. In fact we argue that expectations of economic agents defining trust and confidence influence on length and depth of financial and business cycles. Thus, we provide theoretical explanation regarding fact that financial cycles are much longer than business cycles through introduction of trust cycle as 
additional source of financial fluctuations, whereas this point in the existed literature is limited. The value-added of this paper to the existed literature is that it develops the up-to-date scientific behavioral foundation for the formation of a mechanism ensured further strengthen macroprudential policy at the national and international levels.

\section{Conclusion}

Recent protracted recession after global financial crisis has given a prominent role to revision of sources and drivers of economic development and financial stability both. Behavior of consumers, firms, investors in the world of uncertainty, tough regulation and failure of reliable mechanisms of confidence (including misleading market information, complexity of financial contracts, poor corporate governance) has become one of the macroeconomic policy constraints.

Optimistic and pessimistic sentiments in financial decisions of economic agents can explain business as well as financial cycle fluctuations. Discussing the drivers of cyclical fluctuations, closed interaction and even synchronization between the real and financial sectors is evidenced. Besides, asymmetric information and failings in the rational behavior of agents (behavioral bias) are among empirically proved sources of financial booms and busts. Impact of economic agent behavior in business activity can be regarded through rational ("information" view), semirational and irrational ("animal spirits") frameworks. Hence, our conceptual framework in trust research is calling to show the role of trust in financial and business cycle fluctuations rooted from institutional paradigm. Trust consists of two components - (1) structure-based confidence that is based on objective information about system competences, regulations, formal contracts and norms, and (2) sentiment-based actions of economic agents including those that could be taken under animal-spirits (individual feelings, emotion, and other subjective characteristics). The latter dimension is of utmost importance during periods of major economic shocks associated with high uncertainty and risks, and when the credibility of the system is eroded, removed or questioned. This is demonstrated through developed theoretical descriptive model of trust cycle that allows us to explore several stages of link between financial fluctuations, trust changes, and large swings in business cycle - stage characterized by high level of structurebased confidence and optimistic sentiment-based actions of economic agents, stage characterized by the absence of trust (distrust) resulted from the loss of structurebased confidence and pessimistic sentiment-based actions of economic agents, stage characterized by lack of trust derived from volatility sentiment-based actions of economic agents.

In this regard, in spite of its exploratory nature, this study offers valuable insights into describing the synchronization of financial and business cycles through the trust cycle 
based on the propagation of confidence, waves of optimism and pessimism. This research has gone some way towards enhancing knowledge about the interactions between real and financial sectors during different phases of business, trust and financial cycles. The present study has thrown up questions in need of further investigation. Modelling work is, therefore, an essential next step that need to be made in order to validate this tentative conceptual framework. In order to analyze the duration and amplitude of recessions and recoveries that tend to be influenced by the strength and intensity of trust cycle formed under financial disruptions and stability, a number of regression models could usefully be employed. The concordance statistics and correlation coefficients would be a useful way of examining the extent of synchronization between financial, trust and business cycles. Given importance of these interactions, the future research could examine this issue in a cross-country context using short- and medium-term fluctuations.

The findings of this study have a number of important implications for future practice. In-depth analysis of activities directed towards addressing the consequences of the financial and economic crisis has demonstrated the high costs associated with stabilizing of the financial sector (in form of direct assistance to commercial banks, guarantees and costs for the maintenance of the financial system liquidity) in many countries, and particularly for Ukraine. At the same time, domestic experience of stabilizing has shown chronic underperformance, inconsistency in relation to the time, affect, and influence of some regulatory initiatives and decisions directed at restoring health to the financial sector due to the lack of research findings on the role of public trust in financial sector to foster macroeconomic development. Introduced in this research, theoretical descriptive model of trust cycle and its synchronization with business and financial cycles can be used to develop targeted interventions aimed at the reducing budgetary burden caused by stabilizing measures to transform nonworking temporarily free financial resources into productive capital of the real sector of the economy. Therefore, a tentative conceptual framework could be used among the Central banks current portfolio of work to make adequate informed decisions, intended to promote price and financial stability in national economies, and other regulators in the process of enhancing sound regulation and prudential oversight.

\section{References}

Acharya, S., Benhabib, J., Huo, Zh. (2017) "The Anatomy of Sentiment-driven Fluctuations", Meeting Papers 513, Society for Economic Dynamics, doi: $10.3386 / \mathrm{w} 23136$.

Adrian, T., Shin, H. (2009) "Prices and Quantities in the Monetary Policy Transmission Mechanism" (October 1, 2009). Federal Reserve Bank of New York Staff Report No. 396. Available at: https://ssrn.com/abstract=1483825 [Accessed: September 26, 2018], doi: 10.2139/ssrn.1483825. 
Akerlof, G. (1970) "The market for lemons: Qualitative uncertainty and the market mechanism", Quarterly journal of economics, Vol. 84, No. 3, pp. 488-500, doi: $10.2307 / 1879431$.

Akerlof, G., Shiller, J. R. (2009) “Animal Spirits: How Human Psychology Drives the Economy, and Why It Matters for Global Capitalism", Princeton University Press, Princeton.

Aoki, K., Nikolov, K. (2015) "Bubbles, Banks and Financial Stability", Journal of Monetary Economics, Vol. 74, pp. 33-51, doi: 10.1016/j.jmoneco.2015.05.002.

Beaudry, P., Portier, F. (2014) "News-Driven Business Cycles: Insights and Challenges", Journal of Economic Literature, Vol. 52, No. 4, pp. 993-1074, doi: 10.1257/jel.52.4.993.

Belás, J., Vojtovič, S., Ključnikov, A. (2016) “Microenterprises and Significant Risk Factors in Loan Process, Economics and Sociology, Vol. 9, No. 1, pp. 43-59, doi: 10.14254/2071-789x.2016/9-1/3.

Bernanke, B., Gertler, M. (1989) "Agency Costs, Net Worth, and Business Fluctuations", The American Economic Review, Vol. 79, No. 1, pp. 14-31.

Bernanke, B. S., Gertler, M., Gilchrist, S. (1999) "The financial accelerator in a quantitative business cycle framework", in Taylor, J.B. and Woodford, M., Handbook of Macroeconomics, Elsevier, chapter 21, pp. 1341-1393.

Beugelsdijk, S. (2006) "A note on the theory and measurement of trust in explaining differences in economic growth", Cambridge Journal of Economics, Vol. 30, No. 3, pp. 371-387, doi: 10.1093/cje/bei064.

Beveridge, W. H. (1909) “Unemployment: A Problem of Industry”, Longmans Green, London.

Bidder, R. (2015) “Animal spirits and business cycles”, FRBSF Economic Letter, Vol. 5. Blanchard, O.J., Watson, M.W. (1982) "Bubbles, Rational Expectations and Financial Markets", in Wachtel, P. (Ed.), Crises in the Economic and Financial Structure, D.C. Heathand Company, Lexington, MA, pp. 295-316, doi: 10.3386/w0945.

Blanchard, O. (1979) "Speculative Bubbles, Crashes, and Rational Expectations", Economic Letters, Vol. 3, pp. 387-389, doi: 10.1016/0165-1765(79)90017-x.

Borio, C. (2014) "The financial cycle and macroeconomics: What have we learnt?", Journal of Banking and Finance, Vol. 45, pp. 182-198, doi: 10.1016/j.jbankfin. 2013.07.031.

Borio, C., Furfine, C., Lowe, P. (2001) "Procyclicality of the financial system and financial stability: Issues and policy options", BIS Papers, No. 1, pp. 1-57.

Brunnermeier, M. K., Parker, J. A. (2005) "Optimal expectations", American Economic Review, Vol. 95, No. 4, pp. 1092-1118, doi: 10.1257/0002828054825493.

Calvo, G., Mendoza, E. (2000) "Rational contagion and the globalization of securities markets", Journal of International Economics, Vol. 51, No. 1, pp.79113, doi: 10.1016/s0022-1996(99)00038-0. 
Cashin, P., McDermott, C. J., Scott, A.(1999) "The myth of co-moving commodity prices," Reserve Bank of New Zealand Discussion Paper G99/9, Wellington, doi: 10.5089/9781451858327.001.

Claessens, S., Kose, M.A., Terrones, M. (2012) "How do business and financial cycles interact?", Journal of International Economics, Vol. 87, No. 1, pp. 178190, doi: 10.1016/j.jinteco.2011.11.008.

Clark, J.M. (1917) "Business Acceleration and the Law of Demand: A Technical Factor in Economic Cycles", Journal of Political Economy, Vol. 25, No. 1, pp. 217-235, doi: 10.1086/252958.

Danielsson, J., Marcela, V., Ilknur Z. (2016) "Learning from History: Volatility and Financial Crises", Finance and Economics Discussion Series, No. 093. Washington: Board of Governors of the Federal Reserve System, doi: 10.17016/ FEDS.2016.093.

De Grauwe, P., Ji Y. (2017) "The International Synchronisation of Business Cycles: the Role of Animal Spirits", Open Economies Review, Vol. 28, No. 3, pp. 383412, doi: 10.1007/s11079-017-9434-3.

Dées, S., Zimic, S. (2016) "Animal spirits, fundamental factors and business cycle fluctuations", working paper series 1953, European Central Bank, August.

Di Bella, C. G., Grigoli, F. (2018) "Optimism, Pessimism, and Short-Term Fluctuations", Working Paper No. 18/1, IMF, 5 January, doi: 10.5089/9781484336748.001.

Dow, S (2009) "Market Sentiment and Minskian Financial Crisis: a Keynesian/ agency- structure/psychology analysis", paper presented at the "World Economy in Crisis - the Return of Keynesianism?" Conference, 30-31 October, Berlin. Aavailable at: http://citeseerx.ist.psu.edu/viewdoc/download?doi=10.1.1 .319.1442\&rep=rep1\&type=pdf [Accessed: September 27, 2018].

Drehmann, M., Borio, C., Tstasaronis, K. (2012) "Characterising the financial cycle: don't lose sight of the medium term”, BIS Working Papers, No. 380, Bank for International Settlements, June.

Evans, G.W., S. Honkapohja (2001) Learning and Expectations in Macroeconomics, Princeton University Press, doi: 10.1515/9781400824267.

Fisher, I. (1933) “The Debt-Deflation Theory of Great Depressions", Econometrica, Vol. 1, No. 4 , pp. 337-357, doi: 10.2307/1907327.

Gazda, J. (2008) "Testing Real Business Cycle model in the Polish Economy", Journal of International Studies, Vol. 1, No. 1, pp. 27-35, doi: 10.14254/2071$8330.2008 / 1-1 / 3$.

Gomes, O., Sprott, J. C. (2017) "Sentiment-driven limit cycles and chaos", Journal of Evolutionary Economics, Vol. 2, No. 74, pp. 729-760, doi: 10.1007/s00191017-0497-5.

Gros, D., Roth, F. (2010) "The Financial Crisis and Citizen Trust in the European Central Bank", Working Document No. 334, Centre for European Policy Studies, 26 July. 
Grinderslev, O. J., Kramp, P.L., Kronborg, A. F., Pedersen, J. (2017) "Financial cycles: What are they and what do they look like in Denmark?", Danmarks Nationalbank Working Papers, No. 115, Danmarks Nationalbank, Copenhagen.

Hansen, L. P., Sargent, T. J. (2008) Robustness, Princeton university press.

Harding, D., Pagan, P. (2002) "Dissecting the Cycle: A Methodological Investigation," Journal of Monetary Economics, Vol. 49, No. 2, pp. 365-381, doi: 10.1016/s0304-3932(01)00108-8.

Horta P., Lobão J. (2018) "Global and Extreme Dependence Between Investor Sentiment and Stock Returns in European Markets", Journal of Behavioral Finance, Vol. 19, No. 2, pp. 141-158, doi: 10.1080/15427560.2017.1373647.

Hughes, P. (2010) "Trust: Economic Notions and its Role in Money and Banking". Available at: https://dspace.stir.ac.uk/bitstream/1893/3063/1/PH-Trust\%20Thesis. pdf [Accessed: September 27, 2018].

Jaimovich, N., Rebelo, S. (2007) "Behavioral theories of the business cycle", Journal of the European Economic Association, Vol. 5, No. 2-3, pp. 361-368, doi: $10.1162 /$ jeea.2007.5.2-3.361.

Jlassi, M., Naoui, K., Mansour, W. (2014) "Overconfidence behavior and dynamic market volatility: evidence from international data", Procedia Economics and Finance, No. 13, pp. 128-142, doi: 10.1016/s2212-5671(14)00435-3.

Jorda, O., Schularick, M., Taylor, A. M. (2014) "Betting the house", working paper No. 20771, National Bureau of economic research, Cambridge, December, doi: $10.3386 / \mathrm{w} 20771$.

Jorda, O., Schularick, M., Taylor, A. M. (2016) "Macrofinancial History and the New Business Cycle Facts", NBER Macroeconomics Annual, Vol. 31, pp. $213-$ 263, doi: 10.1086/690241.

Kahneman, D., Tversky, A. (1979) "Prospect theory: An analysis of decision under risk", Econometrica, Vol. 47, pp. 263-291, doi: 10.2307/1914185.

Kahneman, D. (2003) "Maps of bounded rationality: Psychology for behavioral economics", American economic review, Vol. 93, No. 5, pp. 1449-1475, doi: $10.1257 / 000282803322655392$.

Kaminsky, G., Reinhart, C., Vegh, C. (2003) "The Unholy Trinity of Financial Contagion", Journal of Economic Perspectives, Vo. 17, No. 4, pp. 51-74, doi: $10.3386 / \mathrm{w} 10061$.

Keynes, J. M. (1936) The General Theory of Employment, Interest, and Money, New York.

Kiyotaki, N., Moore, J. (1997) "Credit Cycles", The Journal of Political Economy, Vol. 105, No. 2, pp. 211-248, doi: 10.1086/262072.

Kose, M. A., Eswar, P., Kenneth R., Shang-Jin, W. (2009) "Financial Globalization: A Reappraisal”, IMF Staff Papers, No. 56, pp. 8-62. 
Krznar, I., Matheson, T. (2017) "Financial and Business Cycles in Brazil", IMF Working Papers, Vol. 17, No. 12, pp. 1-27, doi: 10.5089/9781475571042.001.

Luhmann, N. (1979) Trust and power: two works, Wiley, Chichester.

Luhmann, N. (1988) "Familiarity, Confidence, Trust: Problems and Alternatives", in Gambetta, D. (Ed.), Trust: Making and Breaking Cooperative Relations, Basil Blackwell, Oxford, pp. 94-107.

Mentel, G., Brożyna, J., Szetela, B. (2017) "Evaluation of the effectiveness of investment fund deposits in Poland in a time of crisis", Journal of International Studies, Vol. 10, No. 2, pp. 46-60, doi: 10.14254/2071-8330.2017/10-2/3.

Merkle, C. (2013) "Financial overconfidence over time-foresight, hindsight, and insight of investors", in, AFA 2013 San Diego Meetings Paper, San Diego, USA.

Mian, A. R., Sufi, A., Verner, E. (2017) "Household debt and business cycles world wide", Quarterly Journal of Economics, Vol. 132, No. 4, pp. 1755-1817, doi: 10.1093/qje/qjx017.

Miess, M., Schmelzer. S. (2016) "Stock-Flow Consistent Modelling of Real Financial Cycles and Balance Sheet Dynamics", Preliminary Work-in-Progress Version for 13th EUROFRAME Conference, Utrecht, June 10. Available at: http://www.euroframe.org/files/user_upload/euroframe/docs/2016/conference/ Session\%2 06/EUROF16_Miess_etal.pdf [Accessed: September 27, 2018].

Minsky, H.P. (1983) "The financial instability hypothesis: An interpretation of Keynes and an alternative to "standard" theory", Critical assessments, Macmillan, London, pp. 282-292.

Nooteboom, B. (1996) "Trust, Opportunism and Governance: A Process and Control Model", Organization Studies, Vol. 17, No. 6, pp. 985-1010, doi: 10.1177/017084069601700605.

Pigou, A.C. (1927) Industrial Fluctuations, London, MacMillan.

OECD (2018) Business confidence index (BCI) (indicator), OECD. Available at: 10.1787/3092dc4f-en [Accessed: September 27, 2018].

OECD (2018) Consumer confidence index (CCI) (indicator), OECD. Available at: 10.1787/46434d78-en [Accessed: September 27, 2018].

OECD (2018) Quarterly GDP (indicator), OECD. Available at: 10.1787/b86d1fc8en [Accessed: September 27, 2018].

OECD (2018) Unemployment rate (indicator), OECD. Available at: 10.1787/ 997c8750-en [Accessed: September 27, 2018].

Prince, T. (2017) "Behavioral Finance and the Business Cycle", Business Ethics and Leadership, Vol. 1, No. 4, pp. 28-48, doi: 10.21272/bel.1(4).28-48.2017.

Reinhart, C. M., Rogoff, K. S. (2009) "The aftermath of financial crises", American Economic Review, Vol. 99, No. 2, pp. 466-472, doi: 10.1257/aer.99.2.466. 
Roth, F. (2009) "Does too much trust hamper economic growth?", Kyklos, Vol. 62, No. 1, pp. 103-128, doi: 10.1111/j.1467-6435.2009.00424.x.

Rünstler, G. (2016) "How distinct are financial cycles from business cycles?", Research Bulletin, European Central Bank, Vol. 26.

Sapienza, P., Zingales L. (2012) "A trust crisis", International Review of Finance, Vol. 12, No. 2, pp. 123-131, doi: 10.1111/j.1468-2443.2012.01152.x.

Schatz, R., Watson, L. A. (2011) Trust Meltdown II, INNOVATIO Publishing Ltd, Fribourg.

Simon, H.A. (1957) Models of Man, New York, Wiley \& Sons.

State Statistics Service of Ukraine (2018) Quarterly GDP (indicator), State Statistics Service of Ukraine. Available at: http://www.ukrstat.gov.ua [Accessed: September 27, 2018].

Stiglitz, J. E. (2000) "The Contributions of the Economics of Information to Twentieth Century Economics," The Quarterly Journal of Economics, Vol. 115, No. 4, pp. 1441-1478, doi: 10.1162/003355300555015.

Tonkiss, F. (2009) "Trust, confidence and economic crisis", Intereconomics, Vol. 44, No. 4, pp. 196-202, doi: 10.1007/s10272-009-0295-x. 
Ciklusi financiranja, poslovanja i povjerenja: pitanja za sinkronizaciju ${ }^{1}$ Yuriy Bilan ${ }^{2}$, Maryna Brychko ${ }^{3}$, Anna Buriak ${ }^{4}$, Tetyana Vasilyeva ${ }^{5}$

\section{Sažetak}

Počevši od 1920. godine, sve veći broj istraživanja usredotočen je na ulogu psiholoških čimbenika u teorijama poslovnih ciklusa. Glavni makroekonomski modeli nisu dostatni za istraživanje interakcije između gospodarskih subjekata, financijskih institucija i realnog sektora gospodarstva. Ovaj rad je među prvima koji pokazuje sinkronizaciju financijskih i poslovnih ciklusa kroz ciklus povjerenja, ali s određenim kašnjenjem. U radu je prikazana konceptualizacija povjerenja kao kombinacija dvaju stupova - povjerenje temeljeno na strukturi objektivnih informacija o sustavnim kompetencijama, propisima i normama, te djelovanju gospodarskih subjekata (osjećaji, emocije $i$ druge subjektivne karakteristike). U radu se primjenjuje teorijski deskriptivni model ciklusa povjerenja koji omogućuje istraživanje nekoliko faza korelacije između financijskih fluktuacija, promjena povjerenja $i$ velikih promjena u poslovnom ciklusu.

Ključne riječi: ciklus povjerenja, poslovni ciklus, financijski ciklus, ponašanje ekonomskih agenata

JEL klasifikacija: E320, E710, G41, O160

1 Ovaj rad ne bi bio moguć bez financijske potpore Ministarstva obrazovanja i znanosti Ukrajine. Rad je pripremljen u sklopu istraživanja mladih znanstvenika na temu "Ekonomskomatematičko modeliranje mehanizma za obnovu javnog povjerenja u financijskom sektoru: jamstvo ekonomske sigurnosti Ukrajine" (registracijski broj 0117U003924).

2 Izvanredni profesor, Fakultet za menadžment, Tehnološko sveučilište Rzeszow, prof. Powstańców Warszawy 12, 35-959, Rzeszów, Poljska. Znanstveni interes: tržište rada, poduzetništvo, energija idruštvo.Tel.: +48 506354648.E-mail: yuriy_bilan@yahoo.co.uk.

3 Viši predavač, Odjel za financije, bankarstvo i osiguranje, Državno sveučilište Sumy, Rymskogo-Korsakova sv., 2, 40007 Sumy, Ukrajina. Znanstveni interes: aplikacija ponašanja i teorije društvenih znanosti $i$ modeli u makroekonomskim fluktuacijama i rastu. Tel.: +38 0542 665-075.E-mail:m.brychko@uabs.sumdu.edu.ua (osoba za kontakt).

${ }^{4}$ Izvanredni profesor, Odjel za financije, bankarstvo i osiguranje, Državno sveučilište Sumy, Rymskogo-Korsakova sv., 2, 40007 Sumy, Ukrajina. Znanstveni interes: ekonomija ponašanja, monetarna policija, bankarstvo.Tel.: +380542 665-075.E-mail: a.buriak@uabs.sumdu.edu.ua.

5 Redoviti profesor, obrazovni i istraživački institut za financije, gospodarstvo i upravljanje pod imenom Oleg Balatskiy, Državno sveučilište Sumy, Rymskogo-Korsakova sv., 2, 40007 Sumy, Ukrajina. Znanstvena pripadnost: bankarstvo, investicije, upravljanje rizicima. Tel.: +380542 687-949.E-mail:tavasilyeva@fem.sumdu.edu.ua. 